\title{
SYSTEMY WYBORÓW SĘDZIÓW STANOWYCH W USA
}

\section{Wstęp}

Federalny ustrój Stanów Zjednoczonych ma swoje odbicie w strukturze sądownictwa. Poza systemem sądów federalnych, istnieje bowiem 50 odrębnych systemów sądowniczych w poszczególnych stanach. Indywidualnie skonstruowane systemy sądownicze oznaczają znaczne zróżnicowanie nie tylko w samej ich strukturze, ale także w sposobie wyborów sędziów, w tym możliwości zastosowania metody wyborów powszechnych, w których obywatele danego okręgu sami decydują, w czyje ręce oddają decydowanie o sporach wynikłych na bazie prawa stanowego.

Warto podkreślić, że amerykańscy sędziowie nie muszą odbywać żadnego dodatkowego szkolenia $\mathrm{w}$ formie np. aplikacji, bowiem dyplom ukończenia szkoły prawniczej i zdanie egzaminu adwokackiego uprawnia w USA do wykonywania w zasadzie każdego prawniczego zawodu. ${ }^{1}$

Celem niniejszego artykułu jest przybliżenie czytelnikowi metod selekcji sędziów stanowych w Stanach Zjednoczonych, ze szczególnym uwzględnieniem metody wyborów powszechnych stosowanej w tym zakresie i wybranych kluczowych problemów będących niejednokrotnie przedmiotem decyzji Sądu Najwyższego Stanów Zjednoczonych.

\section{Sądownictwo federalne i sądownictwo stanowe} - wprowadzenie

Konstytucja Stanów Zjednoczonych uchwalona przez 13 pierwotnych stanów w 1787 roku władzę sądowniczą na poziomie utworzonej federacji przekazała Są-

1 Co więcej, wykształcenie prawnicze nie jest nawet prawnym wymogiem dla nominacji na sędziego federalnego. Kariera sędziowska w Stanach Zjednoczonych nie ma charakteru stopniowego awansowania do sądów wyższej instancji, sędzią sądu najwyższego (nawet Sądu Najwyższego Stanów Zjednoczonych) może zostać i zostaje prawnik, który nigdy nie zasiadał w żadnym sądzie. Zob.: W. Burnham, Introduction to the Law and Legal System of the United States, St. Paul 2006, s. 176-177. 
dowi Najwyższemu oraz „takim sądom niższym jakie z biegiem czasu Kongres ustanowi i utworzy" (art. III kl. 1). Kongres uchwalił ustawę sądowniczą, czyli Judiciary Act już w 1789 roku tworząc federalne sądy niższych szczebli. Sądy te nazywane są „sądami artykułu III", 2 a zasiadający w nich sędziowie cieszą się dożywotnią kadencją i stałym wynagrodzeniem w czasie jej trwania gwarantowanymi przez przepisy samej Konstytucji. ${ }^{3}$

Na poziomie stanowym, system sądowniczy określają właściwe przepisy stanowe. Stanowa konstytucja wskazuje zwykle podstawowy schemat funkcjonowania władzy sądowniczej i określa jej strukturę (a także ogólne metody powoływania sędziów), a szczegółowe rozwiązania przyjęte są przez legislatury stanowe w odrębnych ustawach. ${ }^{4}$

Amerykański system common law przyznaje sędziom szerokie uprawnienia. Sprawują oni, jako władza sądownicza, kontrolę nad władzą ustawodawczą i wykonawczą w tzw. systemie hamulców i równowagi. Mają także możliwość modyfikacji lub uzupełniania istniejącego prawa, a orzecznictwo (oparte na zasadzie precedensu) stanowi ważne źródło prawa w Stanach Zjednoczonych.

\section{Powoływanie sędziów federalnych}

Sposób powoływania większości sędziów federalnych (sędziów artykułu III) określa sama Konstytucja Stanów Zjednoczonych oddając tę kompetencję w ręce władzy wykonawczej i ustawodawczej. Zgodnie bowiem z art. II sek. 2 sędziów Sądu Najwyższego Stanów Zjednoczonych oraz wszelkich niższych sądów federalnych mianuje Prezydent Stanów Zjednoczonych za radą i zgodą Senatu. Warto podkreślić, że ta sama Konstytucja ustanawia dożywotnią kadencję wszystkich sędziów federalnych (art. III sek. 1), a jedyną możliwością ich odwołania jest procedura impeachmentu zarezerwowana dla usunięcia Prezydenta USA i urzędników federalnych (art. II sek. 4).

Powołanie na stanowisko sędziego federalnego to najbardziej prestiżowa nominacja $\mathrm{w}$ sferze sądowniczej w USA. W sądach federalnych zasiada w sumie niecałe

Do tej listy zalicza się także Sąd Handlu Międzynarodowego, w którym zasiada 9 sędziów rozpatrujących sprawy cywilne z zakresu międzynarodowych regulacji handlowych, których stroną są Stany Zjednoczone. Zob. The United States Court for International Trade: http://www.cit.uscourts.gov/ (data dostępu: 11.09.2014 r.).

3 Dodatkowo na poziomie federalnym istnieją także „sądy artykułu I” powołane do administrowania spraw z zakresu kompetencji przekazanych przez stany władzy federalnej właśnie w I artykule amerykańskiej Konstytucji. Są to tzw. sądy wyspecjalizowane takie jak Sąd Odszkodowań Federalnych (U.S. Court of Federal Claims), Sąd Podatkowy (U.S. Tax Court) czy sądy upadłościowe, jako że prawo upadłościowe to prawo federalne, jednolite dla całego terytorium USA. Sędziowie tych sądów powoływani są przez Kongres na określoną kadencję i nie cieszą się bezwzględnymi gwarancjami art. III Konstytucji. Szerzej na temat tych sądów zob. A. Ludwikowska, R.R. Ludwikowski, Sądy w Stanach Zjednoczonych. Struktura i Jurysdykcja, Toruń 2008, s. 25-26.

4 Generalnie można przyjąć, iż w większości stanów istnieją sądy pierwszej instancji (tzw. sądy rozpraw - trial courts) oraz sądy apelacyjne (courts of appeals) - zwykle, choć nie zawsze, ze stanowym sądem najwyższym (supreme court) na szczycie struktury. Szerzej zob. I. Kraśnicka, A. Ludwikowska, Wprowadzenie do systemu prawa Stanów Zjednoczonych, Toruń 2012, s. 197 i n. 
900 sędziów. ${ }^{5}$ Szczytem kariery jest oczywiście stanowisko sędziego Sądu Najwyższego Stanów Zjednoczonych, w którego składzie zasiada 9 sędziów decydujących, zwykle przy ogromnym zainteresowaniu mediów, o sprawach kluczowych dla obywateli amerykańskich (to jest o konstytucyjności przepisów prawa federalnego i stanowego), takich jak współcześnie małżeństwa homoseksualne, ${ }^{6}$ prawo do posiadania broni $^{7}$ czy konstytucyjność obowiązkowego ubezpieczenia zdrowotnego. ${ }^{8}$

\section{Ewolucja sposobów powoływania i wyborów sędziów stanowych}

Przed ogłoszeniem niepodległości wobec Korony Brytyjskiej sędziowie amerykańskich kolonii byli urzędnikami królewskimi, „narzucanymi” z góry i jako tacy symbolizującymi uzależnienie i poddanie Królowi. W przełomowej Deklaracji Niepodległości z 1776 roku jedną z licznych krzywd i przejawów tyranii Króla wobec Kolonii było pełne uzależnienie sędziów (sprawowania ich urzędów oraz wysokości i wypłaty ich wynagrodzeń) od woli Króla. ${ }^{9}$ Dlatego też po uchwaleniu Konstytucji, w początkowym okresie funkcjonowania Stanów Zjednoczonych Ameryki, sędziowie stanowi powoływani byli w większości przez stanowe władze wykonawcze i/lub ustawodawcze, podobnie jak sędziowie federalni. Szybko jednak poszczególne stany wprowadzały elementy wyborów sędziów przez obywateli. Stan Georgia w 1812 roku, a Indiana w 1816 roku wprowadziły takie rozwiązania w swoich stanowych konstytucjach. ${ }^{10}$ Za prezydentury Andrew Jacksona (w latach 1829-1837), we wszystkich w zasadzie stanach pojawiło się oddolne żądanie udziału ,głosu ludu" w procesie wyboru sędziów. ${ }^{11} \mathrm{~W} 1832$ roku Missisipi jako pierwszy stan ustanowiło powszechne wybory sędziów wszystkich szczebli jedyną metodą ich powoływania. Nowy Jork dołączył w 1846 roku. ${ }^{12} \mathrm{~W}$ ciągu następnych kilkudziesięciu lat wszystkie ówczesne stany oraz wszystkie nowo przyłączone do Unii wyłaniały swoich sędziów jeśli nie w całości, to w jakiejś części z wykorzystaniem wyborów powszechnych. ${ }^{13}$

Równolegle z wprowadzenie takiego systemu wyłaniania sędziów pojawiły się głosy krytyki, które z czasem, mocno nasilone i poparte faktycznymi nadużyciami

\footnotetext{
$5 \quad$ Wg danych United States Courts z dnia 31.12.2014: http://www.uscourts.gov/JudgesAndJudgeships/FederalJudgeships.aspx (data dostępu: 09.09.2014 r.).

Np. United States v. Windsor, 570 U.S. (2013).

District of Columbia v. Heller, 554 U.S. $\overline{570}(2008)$.

National Federation of Independent Business v. Sebelius, 567 U.S. __ (2012).

Deklaracja Niepodległości Stanów Zjednoczonych, ogłoszona 4 lipca 1776 roku. Tekst oryginalny dostępny na stronie Archiwów Narodowych USA: http://www.archives.gov/exhibits/charters/declaration_transcript.html (data dostępu: 09.09.2014 r.).

10 L. M. Friedman, A history of American law, New York 2005, s. 81.

11 A. Champagne, K. Cheek, The cycle of judicial elections: Texas as a case study, 29 Fordham Urb. L. J. 907 (2002), s. 907.

12 L. M. Friedman, A history..., op. cit., s. 81.

13 A. Champagne, K. Cheek, The cycle..., op. cit., s. 907.
} 
sędziowskimi, przyczyniły się do powrotu do systemu nominacji sędziowskich pochodzących od władzy wykonawczej. Głównym powodem owej krytyki było upolitycznienie wyborów. W pionierskich stanach Missisipi i Nowy Jork kandydaci na sędziów określali na listach wyborczych swoje preferencje partyjne, stawali się więc elementem ,politycznego młynu”, a to oznaczało uzależnienie od partii i podleganie ich kontroli. W rezultacie pojawiła się kolejna metoda - wyłaniania sędziów w drodze wyborów, ale wyborów niepolitycznych, bez afiliacji partyjnej na kartach do głosowania. ${ }^{14}$ Już na początku XX wieku wielu prawników, w tym były prezydent USA William Howard Taft, stanowczo głosiło potrzebę zmian kategorycznie uznając partyjne wybory sędziów za przejaw braku szacunku dla wymiaru sprawiedliwości. W 1913 roku Albert M. Kales z Northwestern University założył Amerykańskie Stowarzyszenie Wymiaru Sprawiedliwości (American Judicature Society) i rozpoczął pracę nad nową metodą wyboru sędziów stanowych, która uwzględniać miała elementy procedury wyborczej, nominacyjnej oraz oceny merytorycznej poszczególnych kandydatów przez niezależne komisje. Pierwowzory takiej metody wyboru sędziów zostały w kolejnych latach poddane modyfikacjom, aż w 1937 roku Amerykańskie Stowarzyszenie Prawników (American Bar Association) przedstawiło ostateczną wersję niepartyjnej, merytorycznej selekcji sędziów stanowych, tzw. merit-selection plan (plan wyborów merytorycznych). ${ }^{15}$

Pierwszym stanem, który wykorzystał ową propozycję w praktyce było Missouri, gdzie w 1940 roku przyjęto konstytucyjną poprawkę wprowadzającą „Niepartyjny Plan Sądowy” (,Nonpartisan Court Plan”). Zgodnie z nowym prawem selekcja sędziów została poddana wyjątkowej procedurze przebiegającej w kilku etapach. Najpierw niezależna komisja (składająca się z obywateli - prawników i nie-prawników) poddawała ocenie potencjalnych kandydatów na sędziów w efekcie wyłaniając zwycięzców tego etapu i przedstawiała ich gubernatorowi stanu. Gubernator dokonywał ostatecznego wyboru sędziego i mianował go na określone stanowisko na okres zwykle jednego roku. Po tym czasie odbywały się tzw. wybory retencyjne (retention elections), w których to lokalni wyborcy w wyborach powszechnych decydowali o utrzymaniu stanowiska przez sędziego bądź o jego odejściu. ${ }^{16}$

Taki sposób wyłaniania sędziów okazał się ogromnym sukcesem i wkrótce Missouri Plan w bardziej lub mniej zmodyfikowanej wersji zaczęły stosować inne stany. System ten jest dzisiaj statystycznie najczęściej stosowaną metodą wyboru sędziów większości stanów USA (patrz dane przedstawione w kolejnej części artykułu).

14 Ibidem, s. 908 oraz L. C. Berkson, Judicial selection in the United States: a special report, (w:) E.E. Slotnick
(red.), Judicial Politics, Readings from Judicature, Chicago 1999, s. 44.
15 K. Tokarz, Women Judges and Merit Selection Under the Missouri Plan, 64 Wash. U. L. Q. 903 (1986), s. 910-911.
16 S. O'Connor, The Essentials and Expendables of the Missouri Plan, 74 „Missouri Law Review” (2009), s. 485-486. 


\section{Współczesne sposoby powoływania i wyborów sędziów stanowych}

Współcześnie sędziowie stanowi wybierani lub mianowani są w poszczególnych stanach w bardzo różnorodny sposób. Można przyjąć, za amerykańskimi przedstawicielami doktryny, że 50 stanów i Dystrykt Kolumbii stosują „osobliwy patchwork" (,curious patchwork”) obieralnych i nominacyjnych metod selekcji sędziów stanowych. ${ }^{17}$

Wykorzystywane są generalnie trzy metody ukształtowane w procesie opisanym powyżej:

1. Procedura mianowania sędziów, w ramach której istnieje procedura mianowania przez władzę wykonawczą stanu (gubernatora) oraz procedura mianowania przez władzę ustawodawczą (czyli głosowanie przez legislaturę stanową).

2. Wybory powszechne, w ramach których istnieją dwa systemy wyborcze: partyjny (partisan election) polegający na wyborze sędziów w wyborach partyjnych (aby zostać kandydatem trzeba najpierw wygrać wewnętrzne wybory partyjne - tzw. primary eletcions), w których głosuje elektorat danego obszaru wyborczego oraz niepartyjny (non-partisan election) polegający na wyborze sędziów w wyborach, w których głosuje elektorat danego obszaru, ale przy nazwiskach sędziów na kartach do głosowania nie pojawia się ich afiliacja partyjna (w tym systemie kandydaci na sędziów też przechodzą etap selekcji partyjnej, ale ostatecznie głosujący nie znają ich przynależności).

3. Wybór Merytoryczny (Merit Selection) znany także jako Plan Missouri czy Mianowanie Komisyjne polegający generalnie (w wielu swoich wariantach różniąc się poszczególnymi elementami) na wyborze kandydatów na sędziów w drodze specjalnej procedury przez komitety legislacyjne w oparciu o dokonania i kryteria merytoryczne potencjalnych sędziów. Ostatecznej nominacji dokonuje zwykle gubernator stanu spośród trzech-pięciu przedstawionych mu przez komitet kandydatów. W niektórych stanach nominacja gubernatora podlega jeszcze akceptacji stanowej legislatury. Po określonym czasie w głosowaniu powszechnym wyborcy odpowiadają na proste pytanie: Czy sędzia XY powinien pozostać na urzędzie? Tak czy nie ${ }^{18}$

Statystycznie najczęściej obecnie wykorzystywaną metodą wyboru sędziów stanowych jest Missouri Plan. W 15 stanach oraz w Dystrykcie Kolumbia wykorzystywany jest on do selekcji sędziów we wszystkich sądach. W 9 kolejnych stanach

\footnotetext{
17 K. Tokarz, Women..., op. cit., s. 907.

18 Zob. np. L.C. Berkson, Judicial..., op. cit., s. 45 czy Road Maps. Judicial Selection: The Process of Choosing Judges, American Bar Association 2008, s. 5-7.
} 
Wybór Merytoryczny stosowany jest w wyborach sędziów sądów apelacyjnych, natomiast sędziowie sądów niższych instancji wybierani są w wyborach powszechnych (partyjnych lub niepartyjnych). W sumie zatem 24 stany wykorzystują tę metodę, a dodatkowo w 9 kolejnych Missouri Plan wykorzystywany jest w symbolicznym, ale jednak, zakresie w przypadku wyborów uzupełniających na niektórych szczeblach sądownictwa. Kolejną największą grupą (15) są stany, w których wybór sędziów ma charakter powszechnych wyborów niepartyjnych. Partyjne wybory na stanowiska sędziów odbywają się jedynie w 6 stanach. W najmniejszej liczbie, bo tylko w 5 stanach nominacji sędziowskiej dokonuje albo gubernator ( 3 stany), albo legislatura stanowa (2 stany). ${ }^{19}$

Przekładając powyższe na mapę geograficzną Stanów Zjednoczonych nietrudno zauważyć dość silne podziały. Wszystkie stany północne (od Michigan po Waszyngton a nawet Oregon) przyjęły zasadę niepartyjnych wyborów na stanowiska sędziowskie. Dołączyły do nich niektóre stany południowego wschodu - Arkansas, Georgia czy Missisipi wierna swoim pierwotnym założeniom). Partyjne wybory stanowią dominującą metodę wyborów sędziów w 3 stanach na środkowym wschodzie kraju (Illinois, Ohio, Pensylwania) oraz w 3 typowo południowych stanach (Texas, Luizjana i Alabama). Stany środka (od Wyoming, Utah i Arizony po Iowa i Tennessee) przyjęły Missouri Plan - w całości lub w części. Warto dodać, że Missouri współcześnie wykorzystuje system mieszany, gdyż w niektórych sądach pojawiają się wybory partyjne dla obsadzenia sędziowskich stanowisk. Do tej grupy stanów dołączyły odległe geograficznie Nowy Jork, Floryda, większość niewielkich stanów wschodniego wybrzeża (np. Massachusetts, Vermont, Rhode Island) oraz Dystrykt Kolumbii, a także Hawaje i Alaska. Nominacje gubernatorskie utrzymały się w dwóch skrajnie położonych stanach - Kalifornii na zachodzie i Maine na wschodzie oraz w New Jersey. Wirginia i Karolina Południowa to jedyne stany, gdzie wyboru sędziów dokonują władze ustawodawcze (ostatecznego głosowania dokonują w połączonych składach obie izby parlamentów stanowych). ${ }^{20}$ Co ciekawe, podział ten raczej nie koreluje $\mathrm{z}$ tradycyjnym podziałem na stany republikańskie i demokratyczne w kontekście preferencji wyborczych ich mieszkańców. Partyjne wybory sędziowskie mają bowiem zastosowanie $\mathrm{w}$ trzech tradycyjnych stanach republikańskich - Texasie, Luizjanie i Alabamie oraz w trzech demokratycznych - Illinois, Ohio czy Pensylwania. Polityczny prawie wspólny mianownik mają jedynie stany, które pozostały przy metodzie nominacji sędziów przez władzę wykonawczą lub

Na podstawie: Road Maps. Judicial Selection: The Process of Choosing Judges, American Bar Association 2008, s. 7. Przyjęty w tym zestawieniu podział ma charakter ogólny, gdyby bowiem przyjrzeć się dokładnie procesom selekcji sędziów na poszczególnych szczeblach, kombinacje metod wyborczych są bardzo zróżnicowane. Nawet bowiem w przypadku głosowania na stanowiska sędziów przez legislaturę stanową w Karolinie Południowej i Wirginii w procedurze wykorzystywany jest element przygotowania kandydatów przez specjalne komisje. nich stanowych regulacji prawnych w tym zakresie znajdują się w bazie wciąż funkcjonującej American Judicature Society dostępnej na stronie internetowej pod adresem: http://www.judicialselection.us/judicial_selection/ methods/selection_of_judges.cfm?state=VA (data dostępu: 31.08.2014 r.). 
ustawodawczą, chociaż i tutaj spośród „niebieskich” stanów głosujących na partię demokratyczną wyłamuje się republikańska Karolina Południowa.

\section{Kontrowersje wokół wyborów na stanowiska sędziowskie w Stanach Zjednoczonych w orzecznictwie Sądu Najwyższego Stanów Zjednoczonych}

Wykorzystanie wyborów powszechnych (w szczególności politycznych), czy jako podstawowej metody, czy jako elementu procedury w Planie Merytorycznym, skłania do nieustannej (a istniejącej od początku) dyskusji nad niebezpieczeństwami takich mechanizmów i wymiany argumentów między jej zaciekłymi krytykami i gorącymi zwolennikami. Kluczowe problemy w tym zakresie trafiły w ramach prowadzonych postępowań aż do Sądu Najwyższego Stanów Zjednoczonych, którego sędziowie ostatecznie decydują o zgodności amerykańskiego prawa z konstytucją federalną.

Problem upolitycznienia kampanii wyborczej i jej finansowania zdaje się mieścić w sobie największe kontrowersje związane z metodą wyborów powszechnych na stanowiska sędziowskie.

Upublicznianie swoich politycznych sympatii, czy wręcz zdecydowanych politycznych poglądów przez kandydatów na sędziów jest z jednej strony traktowane jako prawo społeczeństwa do informacji o podstawowych wartościach, jakim hołdują kandydaci, z drugiej zaś strony zdaje się przeczyć idei niezależności władzy sądowej. Prowadzenie regularnych kampanii wyborczych przez kandydatów na stanowiska sędziowskie (w tym stanowiska najwyższe w stanowej władzy, takie jak przewodniczący stanowego sądu najwyższego) wiąże się ze zbieraniem funduszy, które rosną lawinowo osiągając zawrotne sumy milionów dolarów w ramach jednej kampanii. ${ }^{21}$ Badania statystyczne i empiryczne prowadzone przez niezależne organizacje i naukowców wskazują, że znaczna większość wyborców (76\%), a nawet prawie połowa sędziów (46\%) uważa, iż kontrybucje finansowe poszczególnych grup interesów mają wpływ na decyzje podejmowane przez sędziów wybranych w takim trybie, a analiza ponad 2300 wyroków stanowych sądów najwyższych zdaje się te obawy potwierdzać. ${ }^{22}$

W ciągu ostatnich lat Sąd Najwyższy Stanów Zjednoczonych kilkukrotnie odniósł się do owych problemów.

21 Kandydaci w wyborach na sędziów stanowych sądów najwyższych w kampaniach między 2000 a 2009 rokiem zdołali zebrać sumę około 211 milionów dolarów, dwa i pół razy wyższą od sumy zebranej w poprzednim dziesięcioleciu. Największe sumy pieniędzy kumulowane były w stanach, gdzie odbywają się partyjne wybory powszechne. Zobacz na przykład raport American Progress: B. Corriher, Partisan Judicial Elections and the Distorting Influence of Campaign Cash, October 25, 2012. Wersja on-line dostępna pod adresem: https://cdn.americanprogress.org/wp-content/uploads/2012/10/NonpartisanElections-3.pdf

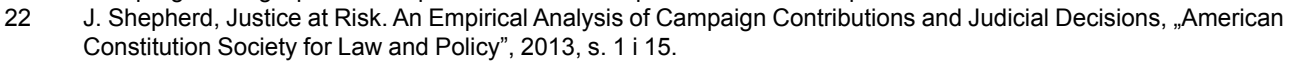


W 2002 roku w sprawie Republican Party of Minnesota v. White ${ }^{23}$ większością 5-4 sędziowie zdecydowali, iż stanowe przepisy obowiązujące w Minnesocie, a zabraniające kandydatom na sędziów ujawniania swoich politycznych preferencji, są niezgodne z Konstytucją Stanów Zjednoczonych naruszając Pierwszą Poprawkę i zawarte w niej prawo do swobody wypowiedzi. Wzmocniło to wolność kandydatów do wykorzystywania emocji politycznych w kampaniach na stanowiska sędziowskie. Istotny wpływ na finansowanie kampanii sędziowskich miało zdecydowanie ostatnie z głośnych orzeczeń w tym zakresie z 2010 roku, w którym (większością 5-4) Sąd Najwyższy uznał, że w kontekście wyborczym nie ma różnicy między prawami wynikającymi z Pierwszej Poprawki dla jednostek fizycznych i przedsiębiorstw, a te ostatnie mają prawo do nielimitowanych wydatków politycznych i kampanijnych, które to nie stanowią elementu korupcji. ${ }^{24}$ Sędziowie Sądu Najwyższego wypowiedzieli się także w sprawie dotyczącej korelacji między darczyńcą finansującym kampanię sędziowską (w rekordowej wysokości ponad 3 milionów dolarów) a udziałem sędziego w rozprawie, w której darczyńca ów jest stroną. Decyzją 5-4 Sąd Najwyższy uznał takie wsparcie za mogące prowadzić do ekstremalnej stronniczości. ${ }^{25}$

Najnowsze orzeczenie $\mathrm{w}$ omawianej problematyce zapadło $\mathrm{w}$ kwietniu 2015 roku w sprawie Williams-Yulee v. The Florida Bar. Po raz kolejny decyzją 5-4 przepisy stanowe Florydy zakazujące osobiste zabieganie o fundusze na kampanię przez kandydatów na sędziów zostały utrzymane w mocy jako nie naruszające Pierwszej Poprawki. ${ }^{26}$

Podkreślić należy wyraźnie, że we wszystkich wskazanych sprawach decyzje zapadały większością jednego głosu, zatem sami „najwyżsi” sędziowie nie mieli jednoznacznych stanowisk w tym zakresie. Co ciekawe, zwycięzcy kampanii na najwyższe stanowiska sędziowskie w sądach stanowych (jak np. pierwsza w historii kobieta na stanowisku przewodniczącego Sądu Najwyższego w Alabamie - Sue Bell Cobb), a także emerytowana sędzia samego Sądu Najwyższego Sandra O’Connor stanowczo od lat argumentują za reformami koniecznymi do eliminacji takich nadużyć i proponują wycofywanie z użycia metod wyborów powszechnych (szczególnie politycznych) dla obsadzenia stanowisk sędziowskich, co z kolei trafia na zdecydowany sprzeciw ich gorących zwolenników. ${ }^{27}$

Wykorzystanie wyborów powszechnych (a co za tym idzie kampanii wyborczej ze wszystkimi jej kontrowersjami i potencjalnymi zagrożeniami dla niezawisłości

Republican Party of Minnesota v. White 536 U.S. 765 (2002).

Citizens United v. Federal Election Commission 558 U.S. 310 (2010).

Caperton v. A. T. Massey Coal Co. 556 U.S. 868 (2009).

Williams-Yulee v. The Florida Bar 575 U.S. __ (2015).

Zob. S. O'Connor, The Essentials..., op. cit., s. 486 i n., J. Shepherd, Justice..., op. cit., Introdcution by Sue Bell Cobb. W odpowiedzi na przykład: Ch.W. Bonneau, In Defense of Judicial Elections, New York 2009. 
sędziowskiej) stanowi oryginalny element specyfiki amerykańskiego systemu sądownictwa, niespotykany w zasadzie w żadnym innym państwie na świecie. ${ }^{28}$

Aktualność kontrowersji potwierdzają kolejne decyzje Sądu Najwyższego Stanów Zjednoczonych. Wskazane (jedynie w sposób powierzchowny ze względu na objętość tekstu) w niniejszym opracowaniu problemy stawiają pod ogromnym znakiem zapytania zasadność takiej metody selekcji przedstawicieli władzy sądowniczej. Decyzja Sądu Najwyższego o niekonstytucyjności wyborów sędziów wydaje się jedynym skutecznym sposobem na usunięcie problematycznych procedur. Jednak biorąc pod uwagę historyczne ugruntowanie wyborów sędziowskich, zaangażowanie społeczeństwa amerykańskiego w życie polityczne i wyborcze, a także prosty fakt, że zdecydowana większość stanów właśnie taką formę uważa za najlepszą, decyzja Sądu Najwyższego jawi się na tym etapie jako zupełnie niemożliwa.

\section{BIBLIOGRAFIA}

Berkson L.C., Judicial selection in the United States: a special report [w:] E.E. Slotnick (ed), Judicial Politics, Readings from Judicature, Chicago 1999

Bonneau Ch.W., In Defense of Judicial Elections, New York 2009

Burnham W., Introduction to the Law and Legal System of the United States, St. Paul 2006

Champagne A., Cheek K., The cycle of judicial elections: Texas as a case study, 29 Fordham Urb. L. J. 907 (2002)

Friedman L.M., A history of American law, New York 2005

Kraśnicka I., Ludwikowska A., Wprowadzenie do systemu prawa Stanów Zjednoczonych, Toruń 2012

Ludwikowska A., Ludwikowski R.R., Sądy w Stanach Zjednoczonych. Struktura i Jurysdykcja, Toruń 2008

O’Connor S., The Essentials and Expendables of the Missouri Plan, 74 Mo. L. Rev. (2009), s. 485-486

Road Maps. Judicial Selection: The Process of Choosing Judges, American Bar Association 2008

Shepherd J., Justice at Risk. An Empirical Analysis of Campaign Contributions and Judicial Decisions, American Constitution Society for Law and Policy, 2013

Tokarz K., Women Judges and Merit Selection Under the Missouri Plan, 64 Wash. U. L. Q. 903 (1986)

28 New York Times opracował zestawienie metod wyborów sędziów na świecie wskazując, że wybory powszechne stosowane jedynie w mniejszych kantorach Szwajcarii oraz jako formalny element procedury wyborczej sędziów Sądu Najwyższego w Japonii. Zobacz: Judicial Selection in Other Countries. New York Times, May 25, 2008. Wersja on-line dostępna pod adresem: http://graphics8.nytimes.com/packages/pdf/national/20080525_judicial_ selection.pdf (data dostępu: 31.08.2014 r.). 


\section{STATE JUDGES IN THE UNITED STATES OF AMERICA}

The article aims to introduce the selection of systems used throughout the United States of America to appoint or elect state judges. It opens with a brief overview of the federal specifics of the courts structure in the USA. The federal system of judicial appointment is subsequently described to provide comparative perspective to the state system. Evolution of the state judge selection methods follow, which provides readers with background on the historical development of the subject with emphasis on the political circumstances in particular periods. Next, currently used selection methods are described including the appointment procedures as well as unique partisan and non-partisan judicial elections, and the Missouri Plan based on merit selection. The penultimate section contains statistical analysis embracing all fifty states and the District of Columbia. Finally, the fifth part focuses on two key problems concerning the partisan election method and the response to those problems provided by the United States Supreme Court.

Keywords: judicial selection, partisan election, non-partisan election, judge appointment, Missouri Plan

Słowa kluczowe: wybory sędziów stanowych, sędziowskie wybory partyjne, mianowanie sędziów stanowych, Plan Missouri 